WIDER Working Paper 2017/114

The politics of scaling up social protection in Kenya

Fredrick O. Wanyama ${ }^{1}$ and Anna McCord ${ }^{2}$

May 2017

United Nations University World Institute for Development Economics Research 
Abstract: Literature on social protection in Kenya shows progress in implementation of cash transfers but not the social health insurance scheme. With a dearth of explanation for this contrasting promotion of social protection, this paper examines the role of Kenya's political settlement and the interests of donors. It argues that whereas the competitive clientelist political settlement is conducive to the supply-oriented cash transfer programmes, it is averse to the demand-oriented social health insurance scheme that requires clients to contribute and also threatens the market interests of donors. The paper therefore concludes that the scaling up of social protection is dependent on the convergence between the clientelist interests of politicians and the motivations of donors.

Keywords: Kenya, social protection, cash transfers, social health insurance, political settlements

Acknowledgements: Thanks to Miguel Niño-Zarazúa of UNU-WIDER, and Tom Lavers and Sam Hickey of the Effective States and Inclusive Development (ESID) Research Centre, University of Manchester, for their invaluable comments on earlier drafts of this paper; also thanks to the informants from Kenyan civil society and government service and representatives of the donor community, past and present, who generously shared their time with us.

\footnotetext{
${ }^{1}$ Kisii University, Kisii, Kenya; ${ }^{2}$ ESID, University of Manchester, UK; corresponding author: fwanyama@hotmail.com

This study has been prepared within the UNU-WIDER project on 'The political economy of social protection systems', which is part of a larger research project on 'The economics and politics of taxation and social protection'.

Copyright (C) UNU-WIDER 2017

Information and requests: publications@wider.unu.edu

ISSN 1798-7237 ISBN 978-92-9256-338-7

Typescript prepared by Gary Smith.

The United Nations University World Institute for Development Economics Research provides economic analysis and policy advice with the aim of promoting sustainable and equitable development. The Institute began operations in 1985 in Helsinki, Finland, as the first research and training centre of the United Nations University. Today it is a unique blend of think tank, research institute, and UN agency — providing a range of services from policy advice to governments as well as freely available original research.
}

The Institute is funded through income from an endowment fund with additional contributions to its work programme from Denmark, Finland, Sweden, and the United Kingdom.

Katajanokanlaituri 6 B, 00160 Helsinki, Finland

The views expressed in this paper are those of the author(s), and do not necessarily reflect the views of the Institute or the United Nations University, nor the programme/project donors. 
This paper examines the political economy of the development of social protection provision in Kenya. The paper argues that in the context of a competitive clientelist political settlement characterized by patronage relations at national, regional, and local levels, social protection succeeds at points where there is convergence between the requirements of the political settlement and the interests and associated resource flows of the international donor community, and it is in these areas that the development of social protection provisioning has flourished. There has been less success where a similar accommodation has not been achieved, and where social protection provision is in tension with the existing political settlement it is less successful. The paper concludes that the social protection agenda in Kenya is defined by the extent of convergence and accommodation between the underlying clientelist interests of political actors and the motivations of external actors, as it relates to programme design, implementation, and financing.

The Kenyan government has implemented a series of cash transfer programmes since the end of the Moi regime in 2002, with over 450,000 direct beneficiaries reached by 2013/14. Social protection has been identified as a key response to poverty in the two national development plans directing national planning since 2003 (RoK 2003, 2007) and has become an electoral issue, included in the manifestos of all the main political groupings by 2012. A range of acts in support of the expansion of social protection provision have been enacted over this period and access to social protection has been identified as a right in the new constitution of 2010 . These developments have been complemented by a range of international donor interventions relating to technical assistance in policy development and programme design and implementation, as well as financing. There have also been attempts to introduce social health insurance during this period, but this has met with less success, such that despite parliamentary and donor support, health insurance provision has not yet been extended to the poor.

This paper analyses the political economy dynamics influencing the adoption and implementation of cash transfers and also social health insurance (SHI), following Lavers and Hickey's (2016) adapted political settlements framework, developed from Khan (2010). The adapted framework focuses on the role of the political settlement-'the balance or distribution of power between contending social groups and social classes, on which any state is based' (Di John and Putzel 2009: 4) — and the distributional regime - the existing mechanisms for distributing resources within society. This approach argues that the adoption and implementation of social protection programmes is influenced by political incentives linked to the political settlement; the degree of 'ideational fit' between proposed policy models and the paradigmatic ideas central to the settlement; and the potential for social protection to address politically significant distributional challenges, using the concept of the 'distributional regime'. The framework accommodates the fact that social protection is not formulated in isolation, but rather is one part of an overall distributional regime that is also influenced by domestic and transnational policy coalitions that advocate policy change (Lavers and Hickey 2016). As such, the analysis focuses on the interplay between contending elite factions and non-elites that underpins Kenya's political settlement, and the interests of external forces in shaping the social protection discourse, and how this has generated political support for the promotion of cash transfer programming, but resistance to the implementation of national SHI provision.

In relation to the clientelism that has characterized successive regimes in Kenya, our analysis suggests that social protection is tolerated and promoted inasmuch as it allows existing systems of patronage at all levels to be maintained and developed, and does not challenge or threaten existing systems of resource control-for example, though changed ministerial mandates or enhanced 
transparency. Notwithstanding a commitment to redress past inequalities and ongoing poverty on some parts, in this context power policy-making will not necessarily have a long-term ideologically driven perspective, unless it is associated with the ongoing identification of additional resource flows and/or the maintenance of meaningful patronage opportunities.

The paper employs a process-tracing methodology within a comparative case study design, involving the application of a set of research activities drawn from a common theoretical framework, and a review of both published and grey literature. To trace the policy-making process, the paper relies on semi-structured, key informant interviews with senior politicians and technical staff within government (seven interviews), representatives of donors and international organizations (14 interviews), and civil society (three interviews). These respondents constitute the key stakeholders, past and present, involved in design and programme administration. These interviews were conducted between April 2015 and June 2016 during fieldwork in Kenya, and also by Skype, and included a number of donor officials who were either currently or previously engaged in the social protection debate in Kenya. The aim of the analysis is to link this policymaking process to the underlying political settlement and policy context.

The existing literature examining political economy in Kenya does not explore the issue of social protection (see, for example, Booth et al. 2014; Sundet and Moen 2009), and the literature on the development of social protection (Bosworth et al. 2016; Handa and Stewart 2008; Ikiara 2009; Nyambedha et al. 2003; UNAIDS 2013; UNICEF/UNAIDS 2003) does not locate the emergence of social protection within a political settlement analysis, or consider the set of competing options and preferences articulated by a range of interest groups of differing power and influence with the political settlement, which have influenced the nature and the scale of social protection that has emerged in Kenya over the last decade, or acknowledge the key role of politics and the specificities of the Kenyan political settlement in shaping the social protection agenda. As such, the significant explanatory value of political economy considerations in the thinking and policy-making around social protection in Kenya have not been explored. With a specific reference to cash transfer programmes and the National Social Health Insurance Fund (NSHIF), this paper discusses the implications of Kenya's political settlement for the adoption and promotion of social protection. The analysis focuses on the interplay between the domestic political settlement and external forces in shaping the social protection discourse and how this has generated outcomes that have broadly supported the promotion of cash transfer programming and resisted the provision of SHI.

The paper is divided into five sections. It begins by analysing Kenya's political settlement and distributional and macroeconomic context, before going on to give a descriptive overview of the main social protection instruments under examination-cash transfers and SHI-and their development over time, followed by an analysis of the political economy factors driving the process of programme and policy development. It then draws conclusions relating the trajectory of social protection provision to the political settlement.

\section{The Kenyan political settlement}

Though Kenya has had relatively stable political institutions since independence, the relationship between the state and citizens has been characterized by political patronage. In this mode of politics, the president and his close associates have sought to control access to state resources to the exclusion of the wider citizenry as a means of assuring their hold on power, with the resources used to reward their supporters in society. Thus, the president and his associates are linked to society through the use of public resources that are reserved for those who support them and 
denied to those who do not. This form of state-society partnership can be historically traced to the political alignments and strategies of the leaders from independence to the present.

Kenya inherited from the colonial government a hurriedly structured multi-party political system under a federal constitution that provided for the sharing of power between the central government and regional authorities (Majimbo). However, both the party system and the constitutional arrangement were at odds with Kenyatta's preference for a one-party political system and a unitary state in which the president exercised executive authority (Oyugi 1992). The approach that he adopted laid the foundation for the politics of patronage in Kenya, using clientelism to create a one-party state within a nominally democratic multi-party process, providing appointments and state resources to those willing to defect to the ruling Kenya African National Union (KANU) (Barkan 1994), resulting in the Kenya African Democratic Union (KADU) dissolving itself and joining KANU in 1964. This marked the foundation of patronage politics in independent Kenya.

The single party burst into factionalism along a range of fracture lines, which were ideological, ethnic, and regional, as well as personality-based, all seeking patronage resources. Kenyatta soon abandoned institutional rule through the party in favour of personal rule (Kanyinga 1995). With personal rule, Kenyatta formalized clientelism as the framework within which Kenyans would participate in the political process, linking the state to citizens through a hierarchy of patron-client networks under the supervision of the chief patron (Kenyatta), from whom political power, authority, and development resources emanated and trickled downwards through a chain of his clients who served as patrons of the various lower hierarchies (Barkan 1984).

Kenyatta formalized and legitimized this system of patronage by introducing the notion of 'constituency service' for Members of Parliaments (MPs), defining their role as assisting constituency self-help projects as a form of 'practical politics' promoted in opposition to the 'empty ideological politics' of the 1960s. In this way, the worth of a politician was assessed in terms of the development resources he could attract to his constituency (Okumu and Holmquist 1984). At the same time, Kenyatta encouraged people to demand assistance from local political leaders for local development initiatives, effectively turning political competition from the national level to the constituency, with the result that both parliamentary and local authority elections were won on the basis of the ability of individual politicians to contribute to constituency development projects. With state resources being channelled through patron-client networks, this meant that only politicians who enjoyed state patronage could win an election.

After initially adopting competitive clientelism, characterized by the presence of many factions competing for power and influence around the patron who recycles them in the governance process to maintain political stability, Kenyatta switched to dominant clientelism in the 1970s, characterized by the existence of a powerful ruling coalition that surrounds the patron to ensure compliance with his directives. In this context the clientelist activities of clientelist factions were tolerated as long as they did not challenge Kenyatta's authority (Barkan 1992). Rather than suppressing leaders who set out to build and fortify their local political power bases, Kenyatta recruited, assisted, and manipulated their efforts to satisfy his goal of consolidating political authority by selectively dispensing or withholding patronage resources, frequently changing alliances with various clientelist factions according to political expediency, while at the same time circumventing any form of outright dissent. This manipulation led groups to compete among themselves to get into the inner circle of Kenyatta's periodic alliances.

This form of clientelism became even more pronounced when Moi took over as president after Kenyatta's death in 1978. Despite pledging to continue with Kenyatta's policies, it soon became apparent that Moi's goal was to redistribute state resources away from the groups and regions that 
formed the power base of the Kenyatta regime to those that would constitute his own (Barkan 1994), shifting the ethno-regional power base. Moi's strategy to achieve this was to curb Kenyattaera patron-client networks by establishing direct control over all arenas of politics in the country. The result was an increase in centralization and authoritarianism and the weakening of national institutions, coupled with an attempt to develop a new dominant coalition that would sideline and replace the patrons of the Kenyatta era.

An attempted coup in 1982 resulted in increased authoritarianism. Moi strengthened both patronage networks and the state machinery that directly linked him to the local level, and curtailed the autonomy of other centres of political power in the country. This involved centralization of the state apparatus and a steady encroachment by the state on civil society to reduce their potential influence in local politics; local organizations were deregistered, co-opted, or simply emasculated to reduce their influence in local politics (Kanyinga 1995). Moi built a dominant coalition of clients that focused on ensuring compliance with his political bidding, and the regime was characterized by intolerance of alternative views and opinions. The introduction of a multi-party political system in 1992 did not significantly change the settlement; the ruling coalition was too strong for the weak and disparate opposition party factions that remained in the periphery.

The Moi era ended on 30 December 2002 following KANU's defeat in the elections. A united opposition coalition, the National Rainbow Coalition (NARC), formed a new government under President Mwai Kibaki. The nature of the political settlement under Kibaki was partly a reflection of the manner in which the coalition was formed and its composition.

Realizing that KANU had won the 1992 and 1997 elections due to the fragmentation of the opposition, 14 political parties, two pressure groups, and a dissenting faction of KANU formed a broad coalition that called itself the Rainbow Alliance to form a single opposition coalition. NARC made electoral commitments to distribute government positions to the leading players of the coalition, carry out a constitutional review, and promote good governance and social development if it won the election (Anyang-Nyong'o 2007).

NARC was a loose coalition driven primarily by the desire to reverse the authoritarianism of previous decades and to extend power beyond Kenyatta's narrow coterie. Some sought to redress the exclusion their regions had experienced in the allocation of public resources during the KANU regime, while others were driven by ideological objectives relating to the reduction of inequality and poverty; this vision was articulated by the new government.

As president of a coalition, Kibaki was the 'first among equals' and relatively liberal in his leadership style, and is credited with opening up political space to facilitate public debate. His laissez-faire style enabled ministers to run ministries without the interference they had experienced under previous regimes, but the regime was also characterized by patronage; the appointment of ministers, permanent secretaries, diplomats, and parastatal executives was based on a combination of ethnic balancing and patronage, and ministers and lesser government officials appointed clients, allies, kinsmen, and supporters to key positions (Masime and Kibara 2003).

This clientelism emboldened Kibaki to renege on some election promises, notably completion of the constitutional review process, which was intended to weaken the presidency by devolving power (Anyang'-Nyong'o 2007; Murunga and Nasong'o 2006), and ideas of social development that some of the coalition members espoused during the campaigns were relegated to the periphery. Clientelist groups subsequently went on to compete among themselves to demonstrate their loyalty to the president, who recruited and dismissed them at will to maximize his decisionmaking power, reinstating competitive clientelism in the governance process. 
The first Kibaki administration ended in 2007, but he returned as president after the contested 2007 elections. To resolve the crisis that followed the election, a power-sharing agreement was brokered, but this left Kibaki dominant and the political settlement of competitive clientelism essentially unchanged, despite the promulgation of a new constitution in 2010 that contained measures intended to curb patronage within government. After coming to power in 2013, Uhuru Kenyatta retained the politics of patronage despite the constitutional obligation to appoint the cabinet from outside parliament, to appoint principal secretaries through a competitive process, and to ensure that the composition of the government reflected Kenya's diversity. Political leaders and ethno-regional elites allied to the president and his deputy sourced the candidates for various posts; those appointed were loyalists to the appointing authority, just like their predecessors (Booth et al. 2014). As such, the Uhuru Kenyatta regime also rides on patronage and continues to govern by means of a settlement based on competitive clientelism.

Social protection gained its first significant foothold in Kenya in 2003 when the political settlement switched from dominant to competitive clientelism during the period of increased policy space and ministerial autonomy. Competitive clientelism has continued to characterize the political settlement since this time, and successive regimes have continued to support the extension of social protection. This support has favoured the implementation of cash transfer programmes, but not the development of social health insurance, both initially mooted in 2003 . We now provide an overview of the socioeconomic context before setting out the trajectory of social protection provision and trace the links between the political settlement and social protection outcomes.

\subsection{The macroeconomic and distributional context}

Kenya has experienced sustained economic growth in the past decade as a result of significant structural and economic reforms initiated in the post-Moi era, and is perceived as an African success and potentially one of the fastest growing economies in Eastern Africa. Kenya's economic performance has been characterized by fiscal consolidation and sound monetary policy that has resulted in macroeconomic economic stability, with inflation and exchange rate depreciation being brought under control and a narrowing current account deficit (IMF 2017). An economic growth rate of 1.2 per cent in 2002 at the close of the Moi regime has since grown steadily as a result of effective macroeconomic policy, reaching 7 per cent in 2007 before falling after the post-election violence to 1.5 per cent in 2008, and then stabilizing at 5-6 per cent between 2010 and 2015. Over this period, income per capita has grown significantly from US $\$ 608$ in 2005 to US\$1,358 by 2014 in current US dollars (CBK 2013; IEA 2012, 2013, 2014; KNBS 2014, 2015; UN Statistics Division 2016). However, the annual government budget deficit grew from 1 per cent in 2007 to 8 per cent by 2015 (KNBS 2016), largely due to the fact that economic growth has not been as rapid as the government had anticipated, resulting in fiscal tightening, with planned cuts in public-sector spending of up to 10 per cent of recurrent expenditure reported in 2016 (Aglioby 2016).

Profound disparities are found in regional economic development, income distribution, gender, and access to social welfare services such as health and education (Kiringai 2006; KNBS 2013), reflecting the historical politicization of resource allocation processes outlined above. Past allocative decisions have resulted in gross inequities and, to some extent, the clientelism and associated weakness of the state continues to perpetuate differences in the sharing of economic opportunities and social welfare services (Okello and Gitau 2006). Despite consistent economic growth, poverty and inequality are persistent, as illustrated by a Gini coefficient of 0.47 (UNDP 2015). The UNDP estimates that 48 per cent of the population of 44 million suffers from 
multidimensional poverty (UNDP 2013), and 47 per cent live below the poverty line ${ }^{1}$ or are unable to meet their daily nutritional requirements (RoK 2012). Half of the rural population and one-third of the urban population live below the poverty line (IFAD 2013; SID and KNBS 2013: 9; World Bank 2013b); poverty varies considerably by region, with the highest prevalence in Turkana County (84 per cent) and lowest (22 per cent) in Nairobi (KNBS 2013). The spatial distribution of Kenya's development is geographically unbalanced, with pervasive regional inequalities reflecting, in part, the ethnic priorities of different clientelist regimes since 1964 (World Bank 2013b).

\section{A descriptive overview of social protection in Kenya}

Prior to 2003, social protection in Kenya was characterized by a large number of small-scale fragmented interventions providing in cash and in-kind support on an ad hoc basis, implemented by a range of government and civil society actors (McCord 2006). This scenario changed following the 2003 elections, and a process of consolidation and development of state-administered national cash transfers was initiated, together with the discussion of the extension of SHI for the poorest, also on a national basis. There are a range of instruments that can be adopted to provide social protection. In this paper we focus on the two that are dominant in the Kenyan discourse: cash transfers and SHI. In the section that follows a brief overview of each of the main instruments developed in the sector is given, and the process whereby they came to be developed is outlined.

\subsection{Cash transfer programming}

Five different cash transfer programmes were introduced in Kenya during the 2000s; the Orphans and Vulnerable Children's Cash Transfer Programme (OVC-CT); the Older Persons Cash Transfer Programme (OPCT); the Persons with Severe Disabilities Cash Transfer Programme (PWSD-CT); the Hunger Safety Net Programme (HSNP); and the temporary Urban Food Subsidy Cash Transfer (UFS-CT). The OVC-CT, OPCT, and PWSD-CT, which are all managed by the Ministry of Labour, Social Security and Services (MLSSS), have been rolled out nationally and are implemented in all counties, while the HSNP is restricted to four counties in northern Kenya that are prone to food insecurity, and the Food Subsidy was only operational for a short period and is now closed. The five programmes are summarized in Table 1.

\footnotetext{
1 In 2005/06, the poverty line was estimated at KES1,562 and KES2,913 per adult equivalent per month for rural and urban households, respectively. This translates to living on less than U\$1 and US\$1.25 per day per person for rural and urban households, respectively.
} 
Table 1: Summary of cash transfer provision

\begin{tabular}{|c|c|c|c|c|c|c|}
\hline Transfer name & $\begin{array}{l}\text { Start } \\
\text { date }\end{array}$ & Eligibility & $\begin{array}{l}\text { Coverage } \\
\text { (counties) }\end{array}$ & $\begin{array}{c}\text { Total no. } \\
\text { beneficiaries }\end{array}$ & Lead agency* & Funding \\
\hline $\begin{array}{l}\text { Orphans and } \\
\text { Vulnerable Children } \\
\text { Cash Transfer }\end{array}$ & 2004 & $\begin{array}{l}\text { Orphans and vulnerable children in } \\
\text { 'ultra-poor' households with a } \\
\text { chronically ill carer and receiving no } \\
\text { other cash transfers }\end{array}$ & 47 & $255,000(2015)$ & MLSSS & $\begin{array}{l}\text { Government and donor } \\
\text { contributions with } \\
\text { increasing government } \\
\text { share }\end{array}$ \\
\hline $\begin{array}{l}\text { Older Persons Cash } \\
\text { Transfer Programme }\end{array}$ & 2006 & $\begin{array}{l}\text { The extreme poor over the age of } 65 \\
\text { who are unemployed and non- } \\
\text { pensionable }\end{array}$ & 47 & $163,000(2015)$ & MLSSS & $\begin{array}{l}\text { Government funded with } \\
\text { donor support }\end{array}$ \\
\hline $\begin{array}{l}\text { Persons with Severe } \\
\text { Disabilities Cash } \\
\text { Transfer Cash Transfer }\end{array}$ & 2011 & Disabled people living in poverty & 47 & $25,000(2015)$ & MLSSS & Government funded \\
\hline $\begin{array}{l}\text { Hunger Safety Net } \\
\text { Programme }\end{array}$ & 2007 & $\begin{array}{l}\text { Households experiencing food } \\
\text { insecurity and poverty }\end{array}$ & $\begin{array}{l}\text { Mandera, } \\
\text { Marsabit, } \\
\text { Turkana, and } \\
\text { Wajir }\end{array}$ & $\begin{array}{l}84,000 * \star \\
\text { households } \\
(2015)\end{array}$ & $\begin{array}{l}\text { National Drought } \\
\text { Management Authority } \\
\text { (NDMA) }\end{array}$ & $\begin{array}{l}\text { Initially donor-funded with } \\
\text { increasing government } \\
\text { share }\end{array}$ \\
\hline $\begin{array}{l}\text { Urban Food Subsidy } \\
\text { Cash Transfer }\end{array}$ & 2012 & $\begin{array}{c}\text { Those in urban informal settlements } \\
\text { experiencing food insecurity in } \\
\text { Mombasa }\end{array}$ & $\mathrm{n} / \mathrm{a}$ & Closed in 2014 & $\begin{array}{l}\text { World Food Programme and } \\
\text { international non- } \\
\text { governmental organizations }\end{array}$ & $\begin{array}{l}\text { Initially donor-funded with } \\
\text { increasing government } \\
\text { share }\end{array}$ \\
\hline
\end{tabular}

* There have been changes to the names and structures of the ministries since the inception of the cash transfer programmes, the most recent of which involved the ministerial reorganization of the MLSSS into the Ministry of Labour and East African Affairs (MLEEA). It is referred to by its previous name, MLSSS, throughout.

** This does not include households receiving one-off emergency support under the HSNP.

Sources: based on Hurell and Sabates-Wheeler 2013; Ikiara 2009; Mathiu and Mathiu 2012; RoK 2016; World Bank $2013 b$. 
Cash transfers were first introduced in 2004, and coverage has accelerated rapidly in recent years. Figure 1 shows the threefold increase in the total number of beneficiary households that took place between 2010/11 and 2013/14, and the significant jump in beneficiary numbers in 2013/14.

Figure 1: Number of beneficiary households by programme, 2010-14

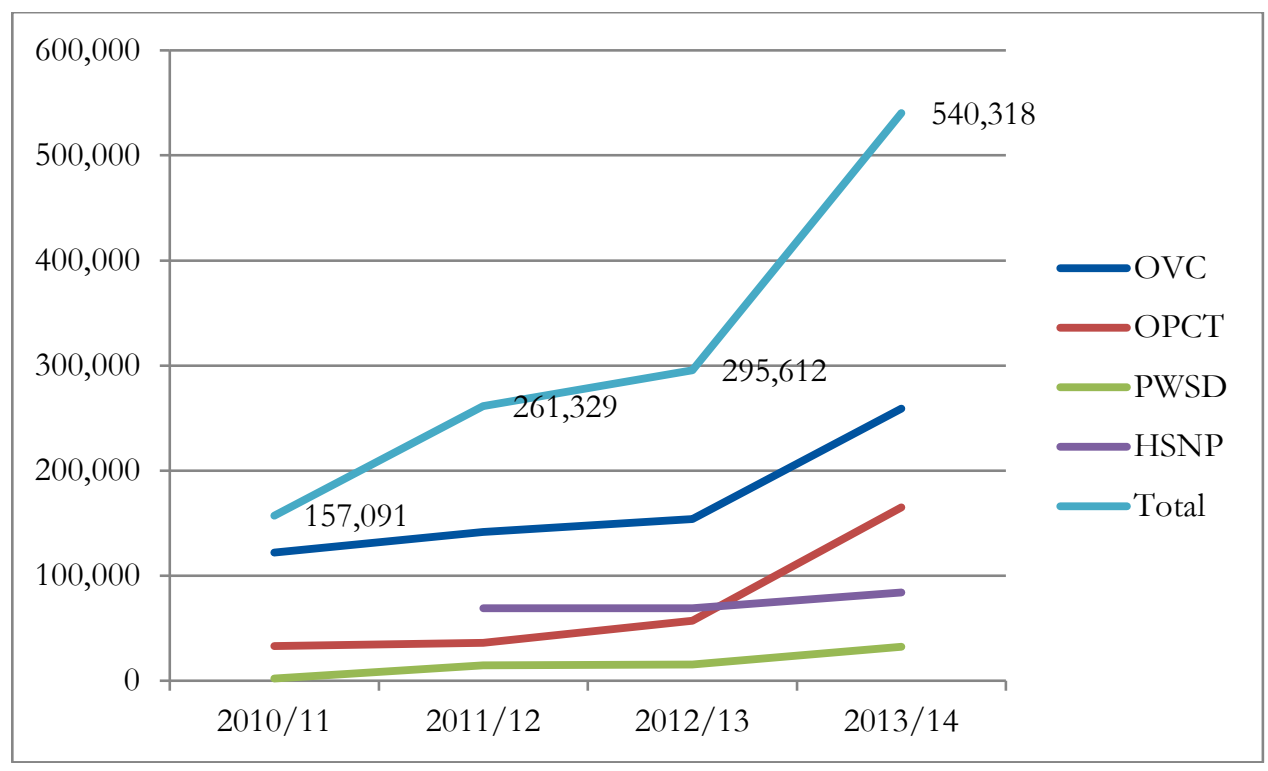

Source: authors, based on data from: MLSSS (OVC, OPCT, PWSD-CT); RoK (2016).

The major increase in the number of beneficiaries occurred in the first year of the new Kenyatta government, signalling the regime's support for cash transfer provision. The government also moved the three MLSSS programmes from pilot to national programme status and incorporated these three, together with the HSNP, into the National Safety Net Programme (NSNP), with the president formally launching them as a concerted programme, the Inua Jamii in February 2014 (Mwasiaji et al. 2016).

\subsection{The political settlement and the evolution of cash transfer programming}

Throughout the 1980s, Moi's KANU government presided over an essentially ethno-regional redistribution of development resources directly informed by the clientelist political settlement, and was not receptive to donor dialogue on social protection or the provision of systematic cash transfers. In the run-up to the 2002 general elections, the opposition campaigned on issues of poverty, unemployment, inequality, and exclusion, as well as poor economic performance. In anticipation of regime change, following the constitutional presidential term limit, donors started to re-position themselves to advance their own priorities in relation to social protection, in line with developments in the global development discourse.

At this time human immunodeficiency virus/acquired immune deficiency syndrome (HIV/AIDS) was identified as a major new development challenge by donors, and new resources and ideas about how to address the challenge provided a major stimulus to the development of social protection across sub-Saharan Africa. A regional United Nations International Children's Emergency Fund (UNICEF) initiative required each country in the East Africa region to prepare a National Plan of Action (NPA), and with additional funding for HIV-related programming becoming available from a number of sources, including the Global Fund to fight HIV/AIDS, tuberculosis and malaria (GFATM), UNICEF initiated efforts to explore the potential for the use of social protection to support orphans and vulnerable children (OVC) affected by the crisis (Save the Children et al. 2005). 
In Kenya the HIV/AIDS pandemic had contributed to a significant rise in the number of OVC, reaching an estimated 1.6 million in the mid-2000s (Bosworth et al. 2016). In this context UNICEF worked with local civil society organizations to lobby candidates for the 2002 parliamentary election to commit themselves to supporting social protection policies and programmes for OVC (Ikiara 2009; Pearson and Alviar 2006), and with most opposition politicians signing up to the UNICEF memorandum, social protection featured prominently in the NARC manifesto for the 2002 elections.

Following electoral victory in 2002, the NARC government turned to its pre-election pledges. Led by the Ministry for Planning and Economic Development, the government launched the 'Economic Recovery Strategy for Wealth and Employment Creation, 2003-2007' (ERS) (RoK 2003) and a range of social policy measures including education, health, housing, and food security were initiated (Ikiara 2009). With the president's laissez-faire approach, ministers were given increased autonomy to develop policy initiatives; in this spirit the Ministry of Home Affairs, which had the mandate for children's affairs, collaborated with UNICEF and other supportive donors on responses to the OVC crisis. A parliamentary committee for OVC was established to explore new options for supporting children affected by HIV/AIDS as there was dissatisfaction with the piecemeal approach of channelling assistance through community-based organizations (Ikiara 2009) and the existing National AIDS Committee and community committee system. MPs on the committee supported the adoption of an alternative mechanism to target and deliver funds directly to families (Pearson and Alviar 2006); the outcome was the development of a pilot cash transfer programme, as recommended in the 2004 Kenya NPA for supporting OVC, in which UNICEF played a leading technical and advisory role (Bosworth et al. 2016).

During this pilot phase the donors created an effective lobby in favour of cash transfer programming; the Kenyan OVC team, officials from the Ministry of Finance, and political leaders were exposed to cash transfer training, international fora, and study tours (Bosworth et al. 2016); the vice-president was co-opted into supporting the scheme, taking on the role of OVC ambassador and champion for funding; and Treasury officials and Ministry of Finance representatives were fully engaged in the policy dialogue, preparing the way for programme endorsement by the government as a key plank of national policy. Between 2007 and 2010 government funding increased tenfold and cash transfers became a politically acceptable mode of redistribution (Bosworth et al. 2016), and by 2014/15 direct funding from development partners ended, although indirect support has continued in the form of World Bank budget support linked to the NSNP.

While the pre-pilot covered only 500 OVC households in three districts, Ministry of Home Affairs and UNICEF advocacy resulted in an extension of the programme to 30,000 households in seven districts by 2006, with further expansion moving faster than planned both in terms of districts covered as well as the government's share of financing. By 2009 the programme was already operating in all 47 districts, with the government's contribution increasing from US\$800,000 in 2005 to US\$9 million in 2009 (Bryant 2009; Ikiara 2009; RoK 2009) as the programme gained political profile and parliamentary popularity.

Lobbying led ministers and MPs to support the concept of cash transfers as a means to address a recognized development challenge and domestic policy priority in a way that was celebrated by the international donor community, thereby satisfying both domestic and international political incentives, while also providing a means for the extension of patron-client relationships in the old tradition. This created space, political legitimacy, and political incentives for the development, piloting, and ultimately national adoption of multiple cash transfer programmes, as the OVC-CT programme served as a model and inspiration for the OPCT and PWSD-CT (Bosworth et al. 2016), which together were to form the core components of the NSNP. 
Subsequent to the introduction of the OVC-CT, the Kenyan government participated the 2006 Livingstone Conference in Zambia, an African Union intergovernmental conference on social protection, hosted with support from donors and INGOs, which set the agenda for the expansion of cash transfer provision throughout sub-Saharan Africa. The resultant 'Livingstone Call for Action', to which Kenya was a signatory, recommended that African countries introduce cash transfer provision not only for vulnerable children, but also for older persons and people with disabilities.

The moral force of the 'Call for Action', backed with promises of donor financing, exposure to the Kalomo cash transfer pilot in Zambia, and experience of the OVC-CT pilot together with lobbying and technical assistance from the INGO HelpAge International, funded by the Department for International Development (DFID), resulted in government initiation of a domestically financed cash transfer pilot to support the elderly in 2006, which drew heavily on the administrative systems of the OVC-CT. This left the disabled the only group identified in the Call for Action for whom the government had not made cash transfer provision. The NARC government enacted the Persons with Disabilities Act and the National Disability Policy early in its administration, in 2003, created the National Development Fund for Persons with Disabilities, and recognized the needs of the disabled in the revised constitution of 2010. Awareness of the success of existing cash transfers strengthened lobbying by the National Council for People with Disabilities (NCPWD) and resulted in 2011 in the government rolling out a domestically funded pilot cash transfer programme for people with severe disabilities-the PWSD-CT.

All three national cash transfer programmes are managed by the MLSSS and are similar in terms of design and implementation, providing a bi-monthly cash transfer of KES4,000 for each enrolled household (National Gender and Equality Commission 2014). Within the MLSSS the directorate of Children's Services manages the OVC-CT, and the directorate of Gender and Social Development manages the OPCT and PWSD-CT using an administrative structure extending from the headquarters of the MLSSS and following the general government administrative structure with national management and oversight, monitoring, and supervision by county-level staff, constituency or district-level coordination of implementation, and community-level involvement. The Social Protection Secretariat (SPS) within the MLSSS has responsibility for coordination across these programmes, while the directorate of Children's Services, the directorate of Gender and Social Development, and the NCPWD, respectively, are responsible for management.

Beneficiary identification was previously carried out by Location Committees (LOCs), mandated to identify potential beneficiaries in each location; their recommendations were validated first during a chief's baraza (a public gathering or meeting) and subsequently through a survey undertaken by the ministry before the beneficiaries were formally registered by the SPS in Nairobi, although selection was widely reported by informants to be informed by the chief's preferences, despite this validation process (see also Kirera 2012). The role of the LOC has recently been taken over by Social Assistance Committees (SACs), which have a preponderance of political appointees, and now manage all cash transfer programmes. The SACs were created as a result of the demand by MPs for direct involvement in cash transfer programme management in their constituencies, and their composition makes the implementation of provision at the county level vulnerable to patronage, particularly given the low coverage and strict rationing of cash transfer provision. ${ }^{2}$ Beneficiary Welfare Committees are involved in programme implementation at the county level

2 This risk has been widely recognized in Kenya; see, for example, the Daily Nation, 8 August 2014: www.nation.co.ke/oped/Opinion/Inua-Jamii-an-idea-whose-time-has-come-/-/440808/2412866/-/tbkdlsz//index.html. 
and have beneficiary representatives from each village, but they are not directly represented on the SAC and do not have a role in beneficiary selection, with their inputs being limited to information sharing and grievance management.

\section{The HSNP}

The HSNP sits differently within the political context, stemming primarily from developments within the international humanitarian sector and in particular DFID's experimentation with alternatives to the modality of addressing chronic food security in the region through annual emergency food aid appeals, given the cost and inefficiency of repeated relief interventions. In this context, DFID explored development solutions as an alternative to repeated humanitarian responses, and the result was the piloting in 2006 of an unconditional cash transfer programme, the HSNP, in four counties in northern Kenya to provide ongoing support for the chronically food insecure, fully funded by DFID. The HSNP provides a bi-monthly payment of KES5,100 to beneficiary households.

The HSNP was administered under the Ministry of State for Development in phase one and the NDMA in phase two, using consultants and international non-governmental organizations (NGOs) to manage the programme directly through a Programme Implementation and Learning Unit (PILU), a contracted body directly financed by DFID. Targeting, management of appeals and grievances, payments, and monitoring and evaluation were subcontracted to NGOs and privatesector partners (World Bank 2013a), and as such was relatively autonomous of government structures. At the county level the programme is managed by the County Steering Committee and the County Technical Working Group, also with significant non-governmental participation.

This institutional approach enabled experimentation in programme design and implementation modalities (including targeting criteria and methods) and reduced the need to accommodate the patronage interests inherent in the political settlement. This was possible in part due to the relative unimportance of northern Kenya within the political settlement. Once established, the HSNP was formalized through a bilateral agreement between the Kenyan and UK governments, and in phase two the programme was transferred to a more conventional line management structure.

The programme, however, remains somewhat anomalous in terms of its design, notably in terms of its technocratic targeting approach that renders it less susceptible to political manipulation than the MLSSS-implemented programmes using the Social Assistance Committee (SOC). In the first phase a combination of community-based targeting (CBT), household dependency ratios, and age (55 and above) criteria were used for targeting (Hurell and Sabates-Wheeler 2013); in the second, which was preceded by creation of a database of 374,000 households, a two-stage selection process took place entailing community wealth ranking and the implementation of a proxy means test (PMT) to create combined CBT and PMT scores to identify 100,000 beneficiary households that were among the poorest 10 per cent in each of the four HSNP programme counties. The government's Commission for Revenue Allocation formula was then used to allocate resources between the counties.

While the programme offers limited opportunities for patronage, it does not represent a clientelist cost, or risk, and as such can be accommodated within the existing political systems, although the lack of opportunity for patronage may account for the relative lack of engagement with the programme on the part of the government to date. It may be characterized as a low-cost, low-gain initiative that represents little threat to the regime, but significant political benefits in terms of donor relations. 
While both the MLSSS programmes and the HSNP are potentially open to politicization and patronage, the HSNP has significantly more checks and balances and a lower degree of direct political engagement in the formal beneficiary selection process. The current donor-led initiative to harmonize the management of cash transfers through the NSNP is partly intended to reduce the potential for the politicization of selection across the MLSSS cash transfer programmes by promoting the HSNP targeting model throughout the NSNP, using disbursement-linked indicator (DLI) incentives. However, it is not clear, given the nature of the political settlement, to what extent the government will accede to the loss of potential for clientelism that this would entail, and that may be a key incentive for ongoing cash transfer support. Progress on revision of targeting practices and outcomes has not been achieved to date, and associated DLI targets have not been met.

Budgetary allocations to the MLSSS programmes increased significantly from 2010/11 onwards, quadrupling between 2011/12 and 2015/16, with the major leap in financing occurring in 2013/14, during the period of rapid expansion of coverage reflecting the nationalization of the three MLSSS programmes in 2014, extending to all 47 counties, and the launch of the NSNP and Inua Jamii, as illustrated in Figure 2. Total expenditure rose sharply, from less than KES5 billion in 2010/11 to KES18 billion (US $\$ 180$ million) in 2015/16, including donor contributions to the OVC-CT. While the HSNP was initially primarily DFID-funded, with a grant of $f^{80}$ million (KES13 billion) for the period 2007-17, the government of Kenya subsequently committed to adding KES4.7 billion (one-third of the cost of the second phase) over four years (NDMA 2014), with the government contribution doubling annually between 2013/14 and 2016/17, an increase in domestic financing that mirrored the increased allocations to the national MLSSS grants.

Figure 2: Total spending on MLSSS cash transfers, 2010/11 to 2015/16 (in KES million)

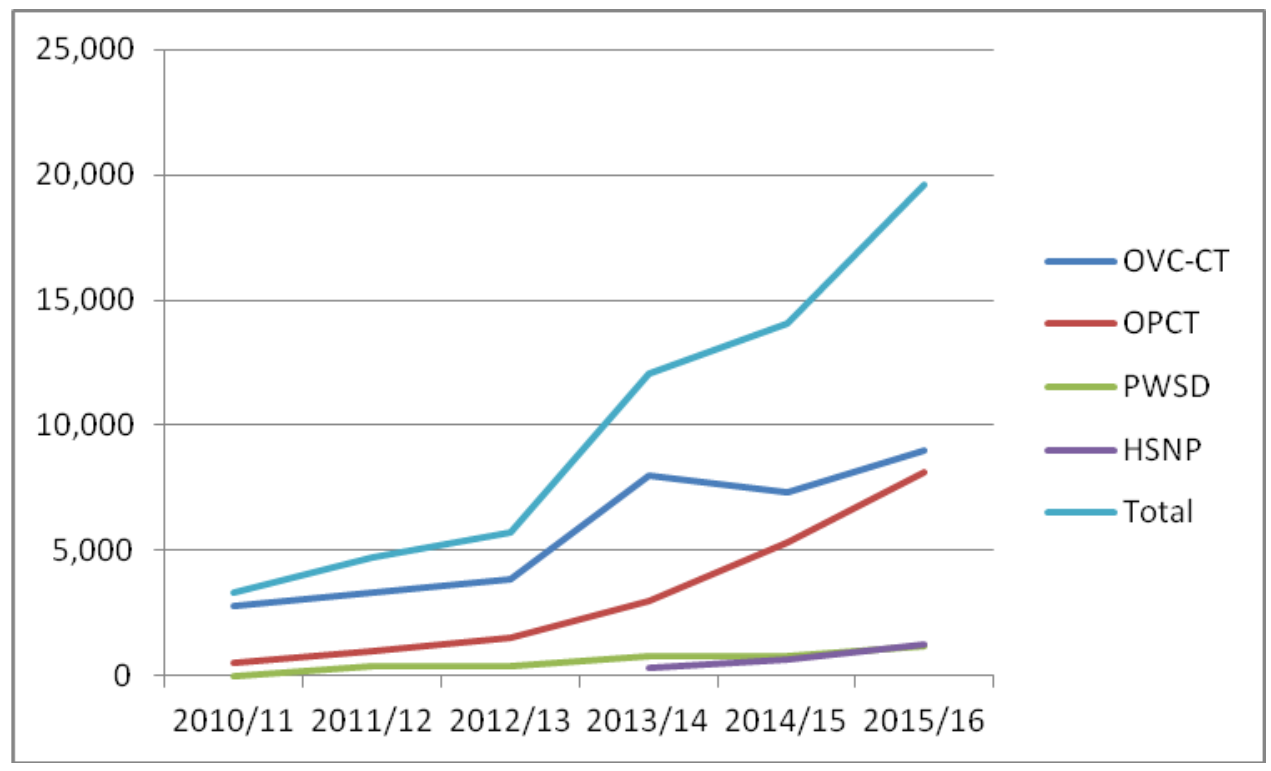

Source: authors, based on IEA 2014; NDMA 2014.

While key informants attributed this increase to the intention of the new government to support the poor and vulnerable groups, as pledged during the 2013 election campaign, the rise in cash transfer financing also corresponds to the period immediately following the introduction of the World Bank-supported National Safety Net Programme for Results (P4R) that pegged US $\$ 250$ million (KES25 billion at 2016 values) of budget support to the achievement of performance indicators linked to the development and implementation of the NSNP. In this way, government investment in cash transfer programming is incentivized inasmuch as it triggers the release of 
budget support that covers the majority of anticipated cash transfer expenditure. This may have contributed to the steady increase in the level of government funding.

\subsection{Social protection policy development}

The provision and expansion of cash transfer programming set out above took place in the context of active government engagement in the development of the legislative and policy context for social protection, with technical and financial support from the donor community, which was concerned to promote the institutionalization and systematization of social protection provision which was initially provided on a project basis without a formal legislative basis.

Social protection was formally included in the ERS (RoK 2003), the national development strategy for the period 2003-07, and its successor, Kenya Vision 2030 (2008-30) (RoK 2007), and also in the new constitution of 2010 (RoK 2010). It is a consistent theme throughout these documents, forming a key component of the social pillar of Vision 2030, one of the four key programme components.

The 2010 constitution obliges the state to support those who are unable to provide for themselves (RoK 2012), making social protection a constitutional right, and addresses commitments in the 2003 Persons with Disabilities Act and National Disability Policy which created a basis for the provision of cash transfer support to this group, while the Kenya National Social Protection Policy of 2011 sets out priorities for achieving these constitutional commitments, and the National Social Assistance Act of 2013 set out a (contested) vision of the institutional context within which this activity should be implemented and coordinated.

\subsection{Social protection outcomes}

Despite the constitutional, legislative, and policy developments outlined above and the significant expansion of budgetary allocations to provision, government expenditure on cash transfers, the main non-contributory social protection instrument was only 0.3 per cent of gross domestic product (GDP), or an estimated 1 per cent of total government expenditure in 2015/16 (based on World Bank GDP data for 2015 and RoK expenditure estimates for 2015/16). ${ }^{3}$ This relatively small overall expenditure is consistent with the fact that although the programmes cover all counties, there are only a limited number of beneficiaries in each, and access to cash transfer resources is highly rationed. Provision does not cover all those eligible; a reach of 540,000 households means that only approximately 2.5 million people, out of a population of 20 million living in poverty, are living in households receiving cash transfer support. Ninety per cent of the poor remain without cash transfer provision.

This problem has been exacerbated by challenges in targeting provision (Kirera 2012; Wanyama and Nyambedha 2015; see also discussion in Bosworth et al. 2016), with significant inclusion and exclusion errors leaving the majority of the poor excluded. Despite this challenge, a decision was taken by the government to extend provision to all counties, rather than focusing on the poorest and increasing the value of the transfer, as recommended by development partners, in order to improve the adequacy of provision and the targeting resources on the poor (McCord et al. 2016). This suggests that extending provision across constituencies may have been a greater priority than ensuring the effectiveness of provision, an issue discussed further below. Effective poverty

\footnotetext{
${ }^{3}$ GDP for 2015 was US $\$ 63$ billion (www.worldbank.org/en/country/kenya) and total government spending for 2015/16 was KES1,500 billion (www.internationalbudget.org/wp-content/uploads/kenya-2016-budget-policystatement-analysis.pdf).
} 
targeting is one of the DLI included in the P4R, as discussed above, intended to reduce the risk of politicized resource allocation, but improved targeting is linked to the release of only US $\$ 20$ million out of a total US $\$ 250$ million package of budget support; as such, significant budget support can be transferred in the absence of any improvement in targeting outcomes.

Despite the political launch of the national Inua Jamii programme in 2014 being associated with a publicly announced government allocation of KES12 billion (US $\$ 120$ million) per annum (Mwangi n.d.), interviews with Ministry of Finance officials indicate that formal plans are not yet in place for the mobilization of domestic resources to cover the full cost of social assistance provision once current large-scale donor support comes to an end. Although donor financing is now indirect, through the P4R, external resources remain critical in funding extended provision, and the cost has yet to be fully internalized by the fiscus. This may raise a question over long-term sustainability. However, it may now be politically difficult for the government to reduce or withdraw provision, given the patronage networks that have grown around it, which may mean that the nature of the political settlement at this point serves to render financing commitments for social protection irreversible, as social assistance has become incorporated as a component of the patronage structures on which the state is dependent.

\subsection{SHI in Kenya}

The development and roll out of SHI to extend access to health and address health-related aspirations articulated by successive post-Moi regimes has followed a very different trajectory from social assistance.

Health financing policy in Kenya has witnessed many changes since independence. The National Health Insurance Fund (NHIF) was established by an Act of parliament in 1964 as a contributory scheme under the Ministry of Health to provide health insurance for salaried public- and privatesector employees earning a monthly salary of KES1,000 and above, while the government subsidized health provision for those outside the fund (Muiya and Kamau 2013). The government withdrew subsidies and introduced user fees in 1989, which were abolished in 1990 but reintroduced in 1992 because of budgetary constraints.

In 1998 the NHIF was transformed from a department of the Ministry of Health into an autonomous State Corporation managed by a Board of Management with mandatory membership for all employees in the public and private sectors (NHIF 2016). The alternative to the NHIF was health insurance provided by private or community-based health insurance (CBHI) organizations. CBHI was introduced in 1999 and covers only a small segment of the population, while private health insurance, the dominant form of health insurance in Kenya, is only accessible to the middleand high-income groups in society (Muiya and Kamau 2013).

When the NARC government came to power with a social transformation agenda, it engaged in discussions with Gesellschaft für Technische Zusammenarbeit (GTZ) and the World Health Organization (WHO), the lead donors in the health sector, to explore options to reduce the outof-pocket burden of health care on the poor through the introduction of the NSHIF, piggybacking on the existing NHIF structures and institutions to provide universal access to health care. The NHIF was known to be highly corrupt, with up to 80 per cent of annual expenditure allocated to non-health-related expenses and characterized by

poor quality service delivery; inefficiency in collections; limited coverage; bureaucratic obstacles (the fund reports to treasury on financial matters and to $\mathrm{MOH}$ on administrative issues); tedious claiming process, with high transaction 
costs that are characterized by fraud and abuse. As such, the fund remains nonaccountable to its members and less responsive to their needs. (IPAR 2005: 1)

The fund was characterized by a lack of transparency that was related to its institutional structure and the political nature of Board appointees. Donors were, however, optimistic that with improved governance and institutional restructuring, the NHIF, could serve as an appropriate medium for SHI provision, and argued that using the existing structure would be more efficient than creating an additional institution; as such, they provided technical advice to address these challenges.

The initiative was championed by the Ministry of Health and a series of technical missions were supported by the lead development partners, WHO and GTZ, who also set up a number of overseas exposure visits for key ministry staff. The development of a national SHI scheme was supported in the 2003 ERS, which specified that the government would enact legislation converting the NHIF into the NSHIF (RoK 2003). An inter-sectoral task force was convened to prepare the requisite national strategy, and legislation was developed in 2003 (Carrin et al. 2007), and the NSHIF bill was drafted and presented to parliament in 2004. The bill proposed transforming the existing NHIF into an NSHIF based on an SHI model with compulsory membership and contributions, premiums pegged to income, and standardized benefit packages. While employee contributions were to be fixed as a percentage of wages and salaries, government contributions would allow for the inclusion of poor households unable to contribute (Carrin et al. 2003; Ministry of Health 2004), with access to services dependent on individuals' needs and contributions based on members' ability to pay (IPAR 2005). In terms of governance, the bill proposed that the scheme should be controlled by the government through the Ministry of Health which was to be responsible for the fund and exercise general oversight over its activities, with the support of a Board of Trustees, of whom the majority were to be nominated directly by the government.

The NSHIF bill was passed by parliament in 2004, but the minister of finance challenged the bill on grounds of affordability (Hakijamii Trust 2007), and Kibaki subsequently refused to give presidential assent, returning the bill to parliament, where it lapsed in 2008. Subsequent attempts by the minister for medical services to revive the bill and the NSHIF concept have been unsuccessful (Abuya et al. 2015), despite the continued prominence given to it in the Vision 2030 (RoK 2007). Donor support for the development of an SHI as a means to universal health care has waned, and progressive extension of the existing NHIF has been characterized by ongoing governance challenges that have resulted in dissent and scandal (see, for example, Mung'ahu 2013), leading a recent review to conclude

We find that NHIF is not even minimally transparent. If the corporation is going to continue to increase its management share of public health resources, and to eventually act as the principal financier in a universal health insurance scheme in Kenya, it must improve its transparency and financial management practices (Lakin and Magero 2012).

The World Bank is currently supporting the development of an alternative intervention, the Health Insurance Subsidy Programme (HISP), to be implemented within the framework of the existing NHIF (World Bank 2013c), and adopting a market-oriented health insurance approach rather than the socialized concept set out under the NSHIF. The HISP aims to provide comprehensive coverage to nine million people living in extreme poverty by 2020, with World Bank financing for the initial phase of the programme (Mwaura et al. 2015; World Bank 2013c). 
While the implementation of cash transfers has been a story of progressive increases in spatial and numerical coverage and the extension of provision to a range of vulnerable groups since 2004, SHI provision did not progress in a similar way following parliamentary endorsement in 2003; efforts to roll out SHI have been effectively resisted for more than a decade. We now explore the implications of Kenya's political settlement for these divergent outcomes and the explanatory value of political economy considerations in relation to social protection policy-making in Kenya. The analysis focuses on the interplay between the domestic political settlement and external forces in shaping the social protection discourse and how this has generated outcomes that have broadly supported the promotion of cash transfer programming and resisted the provision of SHI.

\subsection{The political economy of the policy and legislative context}

Just as the political settlement conditioned the evolution and implementation of cash transfer programmes, politics has been at the core of the policy and legislative context and of efforts to consolidate the administration of cash transfer programmes in the country.

Cash transfer programmes were initially developed through a piloting process and without a policy or an operational law to govern them. Similarly, the National Social Protection Secretariat (NSPS) was set up within the MLSSS without any form of enabling legislation. To address these deficits, the Kenya National Social Protection Policy (NSPP) was adopted in 2011 and the Secretariat worked with civil society and politicians to draft the National Social Assistance bill, which was enacted in 2013, to formalize its institutional position and provide a legal basis for its social protection activities.

Although the MLSSS had supported the drafting of the bill and lobbied for it in principle, they objected to its final content in terms of the proposed institutional structure (which they argued was inconsistent with the institutional vision of the NSPP), which failed to take into consideration the existing structures for programme implementation. Hence the Act was never brought into effect by the minister and, instead, the institutional structure set out in the NSPP was retained, and an alternative National Social Protection Council bill was promoted as the basis for the formalization of the NSPS.

An analysis of the two proposed structures shows key differences; whereas the Policy put the administration and management of social protection programmes under the National Social Protection Council (NSPC), the Act proposed the establishment of a National Social Assistance Authority (NSAA) to play this role. More fundamentally, whereas the Policy envisaged the NSPC to comprise of 'representatives of the Government ministries engaged in social protection and of non-state actors such as the private sector, employers, workers, development partners, community groups, and voluntary organizations' (RoK 2011), the Act made the NSAA relatively autonomous, with a management Board chaired by a competitively recruited person, appointed by the minister in charge of social security and services (RoK 2013). Also, whereas the Social Protection Policy stipulated a management structure that runs from the NSPC and a SPS hosted by the ministry in charge of social security and services to administrators and committees at county and sub-county levels, the Act's NSAA had the power to establish its own branches in the country and raise funds for social protection. These comparisons suggest that while the Policy conferred management power to, and located the entire administrative structure for social protection within, the MLSSS, the Act made management of social protection relatively autonomous from the ministry, and potentially more vulnerable to interference by the minister. As such, a possible interpretation of 
the objection by the ministry to implement the Act could be the drive to retain the administrative power to control the management of social protection programmes.

Senior civil servants attributed the weakness of the Act to the haste in which it was prepared just prior to the 2013 elections. However, the Act involved the formation of an autonomous body for the delivery of social protection, which would no longer be directly answerable to the MLSSS, or directly managed by local government and MPs, and as such represented an alternative political control option for an increasingly high-profile and well-resourced institution, which would entail the loss of access to political and financial resources for incumbent actors, and as such was a threat to some dimensions of the existing political settlement. This led to an unwillingness on the part of the MLSSS to cede power or recognize the authority of the new Act. The challenge to the existing distribution of social protection-related rents was not accommodated, despite its status as a legally enacted Act endorsed by parliament. While the SHI bill was approved by parliament but never given presidential approval, and so lapsed, the NSAA bill was approved by parliament, but was never acted upon by the key institutions it governed. Both examples indicate the qualified and contingent nature of a parliamentary mandate in relation to social protection.

An interest in streamlining the management of cash transfer programming has led donors to drive the government to introduce the Kenya NSNP, with the aim of improving the efficiency of social protection provision and establishing a sustainable national social protection system, and creating a set of fiscal incentives to promote compliance. The objectives of the NSNP, and the associated P4R, negotiated by the World Bank and the government of Kenya in 2013 (World Bank 2013a: 15), are: to strengthening cash transfer programme governance by creating a single registry (for beneficiary targeting, registration, payment, and monitoring); harmonizing programme design and implementation to improve consistency; and expanding coverage in a coordinated and povertytargeted manner, while also increasing government ownership (World Bank 2013a). These objectives are in tension with the current political settlement, inasmuch as they challenge the existing patronage networks that inform governance, and donors have attempted to address this by creating an incentive within the P4R that compensates for the potential patronage loss that could ensue; according to this system, budget support funds are released subject to the achievements of targets linked to the objectives, following nine DLIs. A total of US $\$ 250$ million are due to be disbursed over a five-year period against the realization of targets for these DLIs.

Forty per cent of the P4R funds are, however, available to the government for expanding cash transfer programme coverage, irrespective of targeting or administrative changes, which would threaten the existing clientelist benefits of the transfer programme (World Bank 2013b). Expansion of coverage is the major area where donor and government interests converge, and this augurs well for a regime that has a major political stake in increasing beneficiary enrolment, and as such, expansion has been the major government focus to date. Progress on targeting and accountability related aspects of the DLIs has been significantly slower. P4R incentives may have been instrumental in some administrative change, including progress on the promotion of electronic identification processes, developing a single registry and functional information management system (MIS), and promoting domestic financing of the NSNP in line with DLIs to trigger the release of tranches of budget support. By August 2015, the government had achieved seven of the DLIs and was in the process of finalizing the establishment of a single registry with a functional MIS to constitute the eighth DLI (World Bank 2013b).

Accommodation of donor strategies and conditions for the consolidation of cash transfer programming seems likely when the potential clientelist benefits outweigh the costs in terms of securing resources to finance ongoing social protection commitments and satisfy the clientelist pressures that emanate from the political settlement. However, the fact that the National Treasury does not have explicit medium-term plans for continued domestic financing of social protection 
beyond the period of $\mathrm{P} 4 \mathrm{R}$ support questions the extent to which there is an ideologically, rather than politically, driven commitment to social protection provision within government.

Cash transfers have been supported inasmuch as they serve to preserve or extend clientelist relationships, becoming increasingly popular with MPs as they realized the potential of cash transfers as a means to extend the resources available for discretionary distribution at constituency level, effectively extending the long-established 'constituency fund'. Where donor programming has resulted in attempts to constrain ministry or local political control over cash transfer resources, it has been resisted, and only where transfer administration autonomy has not been seen by the regime as a threat, in terms of diminishing patronage opportunities, has it been tolerated-as in the case of the HSNP, operational only in four politically marginal northern districts.

\subsection{The political economy of the development of SHI}

While the various cash transfers provided new or increased opportunities for clientelism, the debate around SHI poses a very different set of risks to the political settlement, including significant recurrent fiscal liabilities that are not externally financed, loss of control over a major pool of health funds currently accessible by the Ministry of Health and a range of politically nominated Board members, the alienation of influential clients through increases in direct costs and reduction of commercial opportunities, and the disaffection of large numbers of public-sector workers. These challenges and their linkage with the political settlement are set out below.

Although passed by parliament in 2004, the NSHIF bill was subject to criticism from a range of key actors, including the private sector, unions, the Ministry of Finance, donors, and the general public, and failed to receive presidential support. Unions rejected the financial implications of cross-financing of the poor and also highlighted concerns regarding the capacity and transparency of the NHIF; the Ministry of Finance articulated concerns relating to affordability; and the private sector feared a depletion of its potential consumer base. The subsequent reluctance of the president to endorse the bill may therefore be understandable in the light of the concerns of multiple political stakeholders, which a competitive clientelist regime cannot afford to alienate. Thus, the manner in which the government has handled the SHI scheme and its ultimate failure can be understood in terms of the nature of the political settlement in Kenya.

Arguably, while the NARC government was motivated to introduce SHI as a means to improve access to health care as part of the package of social reforms forming part of the post-2002 mandate to redress the failures of the previous regime, the fact that the government operated under a competitive clientelist settlement meant that it also had to accommodate the interests of influential clients, among whom were private health insurers and health management organizations resisting business competition (CGD 2004). These interests ultimately dominated ideological concerns relating to the extension of health care provision, resulting in the failure of the SHI initiative.

In the interest of protecting their businesses, stakeholders identified a number of concerns with the NSHIF proposal, including potentially detrimental impacts on the quality of health care in private hospitals, rejection of the principle of cross-subsidy by the middle class, government inefficiency and corruption, particularly in relation to the existing NHIF, and a lack of detailed information on the cost implications of the NSHIF. They argued that the poor should be protected via a direct budgetary allocation from the Ministry of Health rather than an extended and restructured version of the existing NHIF (Carrin et al. 2007).

In addition to these private-sector concerns, the Federation of Kenya Employers, professional associations, and trade unions had reservations relating to the cost of the NSHIF and its 
implications in terms of higher contributions and reduced employee benefits, and the social unrest this might generate; they also raised concerns relating to the governance of the NSHIF, given the levels of corruption and mismanagement in existing government institutions. The public was also critical of the government's dominance in the management of the scheme, given its poor record of managing public institutions, including the NHIF, and the recognized potential for political manipulation (Carrin et al. 2007).

Donors who had supported and sponsored the initiative were also concerned over the design and governance of the scheme as proposed in the bill prepared by the ministry, which did not reflect the institutional revisions to the NHIF they had proposed, which would have addressed the risks of inefficiency, corruption, and potential politicization of the fund, and at this point donor support for the initiative waned. Informants indicated that the donor community coalition split at this point, with some wanting to build on the momentum already achieved and the existing bill, despite its institutional weakness, while others required more significantly developed cost and financing plans and institutional safeguards prior to the provision of further support; when these failed to materialize, donor championship of the initiative effectively ceased.

With such a range of resistance, the political cost of supporting the scheme would have been high, and neither Kibaki nor his successors have been willing to make the governance changes that would have promoted confidence in the NHIF's capacity and credibility, or to promote free health care at the point of use, due to the associated risks of alienating a range of key clients, within government and also within the corporate sector and unions (both consumers and providers of health care, and as clients and potential beneficiaries of fund largesse). The SHI would have had a direct or indirect cost to many key clients, reversing the logic of the clientelist settlement whereby clients are in receipt of resources from the patron, and as such while progress towards SHI and universal health coverage would have promoted development outcomes, it would also have entailed a significant patronage tradeoff at multiple levels, and potential political gains from supporting the poor were not commensurate with the political losses that would be sustained should the initiative have been pursued.

In this way the NSHIF trajectory has been significantly influenced by the political settlement. A competitive clientelist regime is, above all, dependent on supporters, rather than ideologically committed to provision for the poor or a medium- to long-term development perspective, and as such is essentially 'survivalist' in nature. These features partly explain why the state in Kenya succumbed to stakeholders' resistance to the implementation of NSHIF despite an interest in extending access to health care for the poor. With a vision that is focused on retaining power in the short to medium term, a regime based on competitive clientelism will withdraw from initiatives that threaten the political settlement.

\section{Conclusion}

The examination of the process of social protection policy and programme development in Kenya since 2003 indicates that the nature of the political settlement is influential in shaping outcomes.

There has been significant progress in developing the legislative and policy structures to support provision, including a commitment in the 2010 constitution, together with an increasing fiscal commitment, largely donor supported, and a rapid expansion of cash transfer coverage. However, where the realization of constitutional or legislative commitments would have a cost to the political settlement by disturbing clientelist relationships through a reduction in opportunities for patronage, or result in costs rather than benefits to key clients, less progress has occurred. As such, 
legislative and policy commitments have been acted upon inasmuch as they are consistent with competitive clientelist imperatives, maintaining and promoting patronage links at both individual and institutional levels, and initiatives have failed where they have served to challenge or weaken patronage at central or local levels. If the political cost is too high, clientelist interests dominate broad ideological orientation, which is mutable, and while commitments may be made in policy statements, acts, and donor agreements, implementation may be managed in such a way that the clientelism at the centre of the political settlement is not disturbed. This tension between external ideation, ideological orientation, and the political settlement relates primarily to a struggle for control over resources, which is visible in the negotiations that have taken place around social assistance and SHI over the last decade, and the way the Kenyan government has engaged with donor attempts to curb the politicization of the sector.

Change in the political settlement provided opportunities and also impetus for policy change, both in terms of political space, and also in terms of policy content. The change of regime from KANU to NARC in 2003 effectively changed the political settlement to one characterized by competitive clientelism, which had the effect of opening up the political space for policy discussion and inclusion of civil society and donors in public policy consultations. It also allowed ministerial autonomy for programme development coupled with a commitment to redress the developmental imbalances created by the previous regime. At the same time, these programmes were also important in bolstering competitive clientelism by providing additional resources for distribution at the constituency level. Consequently, the successful initiation of cash transfer programmes in Kenya was made possible by the return to a competitive clientelist settlement in 2003 . The previous regime had no political need to experiment with cash transfers, whereas NARC came to power explicitly on the ticket of addressing both geographical and political exclusion, and as such it had the expectations of a broad network of supporters to satisfy, within a development narrative that included social policy and poverty reduction. This created an opening for the development of policy in line with dominant development discourses of the period, and resulted in a series of national development plans and a new constitution that reflected this narrative, serving to satisfy both the domestic and international development audiences, while also strengthening systems of patronage. It also allowed ministers to develop their own programmes and develop associated systems of patronage as long as they were aligned with the interests of the broader political settlement, allowing key individuals to champion policy and programming developments, and the state to benefit from international endorsement within the donor community.

While UNICEF lobbying for cash transfer provision began prior to the 2003 election, detailed discussions regarding cash transfer programme development started only after regime change. What occurred in 2003 was an opening of policy space at a time when donors had ideas to test, alongside funding and technical expertise resources to back them. At the same time it was apparent that these programmes had the potential to support the competitive clientelist political settlement on which the new regime was based, by providing additional resources for distribution constituency level, and which being highly rationed, rather than universally available, could be used as an instrument of reward. As such, cash transfer programming satisfied both the ideological poverty reduction and development aspirations of the new regime, while also being consistent with the competitive clientelist tradition and also playing to donor priorities relating to both social protection and also the HIV/AIDS crisis. As such, cash transfers fulfilled multiple national and local political priorities as well as donor interests simultaneously. These multiple benefits were recognized by Kenyatta, as indicated by his formalization of the programmes into the national Inua Jamii programme the year after he came to power, the significant extension of government financing, and the explicit linking of MPs to beneficiary selection processes (Mwangi n.d.).

The initiation of social protection policy in Kenya was not driven by domestic ideological imperatives, but rather was the result of problem framing by the donors, and by global policy 
advocates in a context in which donor interests converged with those of the political settlement. Regional and national policy coalitions introduced (and funded) ideas that became paradigmatic and were subsequently incorporated into the political settlement, introducing pilots that were integrated into formal institutions as the value of cash transfers in strengthening the clientelistic relations, and hence the regime in which they were embedded, became increasingly apparent.

One result was the development of a strong policy and legislative basis for social protection, with significant donor support, notably the ERS and Vision 2030, the 2010 constitution, and the 2011 Kenya NSPP, which is anchored in the provisions of the constitution. The response to poverty by successive governments since 2003, as articulated in these documents, has been significantly shaped by donor coalitions, most particularly the UNICEF OVC programming of the early 2000s, the Livingstone Conference of 2006, and the World Bank experimentation with the P4R process, each of which has shaped policy choices made by the government in terms of the specific forms of social protection adopted. The competitive nature of the settlement has allowed for a tolerance of donor experimentation inasmuch as it did not threaten existing patronage systems.

In this context the nature of the institutions and their roles within the political settlement have been key to shaping outcomes, with those integral to clientelistic relations such as the NHIF being protected by the regime from transformation, to the detriment of the development of SHI, and with new institutions with the potential to strengthen patronage developing around the cash transfer process, such as the SAC. Social protection initiatives have flourished or failed contingent on their ability to be incorporated within the political settlement, with the centre protecting and promoting opportunities for ministerial control and clientelism and resisting attempts to reduce it.

Politics are central to the development and implementation of these programmes. Politicians consider cash transfer programmes to be part of the resources for oiling their clientelist linkages (Mwasiaji 2015), and as such political patronage has infiltrated the process of selecting beneficiaries, given the political recognition that cash transfers can yield electoral returns (Mwasiaji 2015). At the local level under both the previous LOC and the new SAC, targeting weaknesses have been identified as a major challenge (see, for example, Kirera 2012; Wanyama and Nyambedha 2015), with the politicization of targeting and management of the programmes' entrench patron-client politics.

During their piloting phases, cash transfers were not perceived by politicians as instruments of political leverage, and consequently there was little political interest in the selection of beneficiaries or competition for the extension of programmes across all constituencies. However, as the scale and profile of programmes has grown they have attracted political attention, resulting in the demand from MPs for the extension of provision to all constituencies and a greater role in implementation.

Addressing the demand for provision of resources for cash transfer provision across all constituencies was also an attempt by the central government to soothe tensions relating to the regionalized nature of political organization, and to diffuse criticism that the government was wooing opposition-dominated areas to the detriment of its own supporters. Hence, universal constituency coverage served to reinforce political patronage at national, as well as local, levels and the priority of addressing these concerns weakened support for alternative, poverty-based resource allocation approaches (Wanyama and Nyambedha 2015). The bottom-line in a competitive clientelist political settlement is the promotion of increased beneficiary numbers, and the political benefits of cash transfer programmes are leading some politicians to initiate (and finance using county resources) their own supplementary cash transfer schemes as a means of consolidating their support bases (Wanyama and Nyambedha 2015). Though clientelism was not an explicit motivation in the initiation of the programmes, they have to some extent become captured by MPs 
as an additional source of patronage resources, and the net effect of this has been a steady demand for the expansion of geographical coverage, the number of beneficiaries, and budgetary allocations.

The roles of both ministers and ministries have also been significant in driving and shaping policy and programming outcomes, as they have promoted the ideological narrative within which provision is framed, and competed to maintain control of the associated resources. Both the SHI and the OCV-CT had policy champions in the ministers who worked with donor coalitions on the ideation and popularization of provision. The settlement accommodated individual policy champions and the popular profile they attained in relation to their portfolios, and the minister of labour and social security played a key role in championing and developing the cash transfer programmes, using the policy space provided by regime change in 2002, and gaining domestic and international recognition in the process. The ministry as an institution then worked to ensure the retention of control over the institutional and financial resources gained in the process, rejecting legislation and governance innovations that challenged this. Similarly, the Ministry of Health Services rejected the bill that would have reduced its control over the resources of the NHIF. A consistent thread is an acceptance of the problem framing and policy ideas contributed by donors and civil society, balanced with resistance and contestation where this might challenges existing governance structures to the detriment of the broader political settlement, and its clientelist basis. As such, we see a broad tolerance and endorsement of social protection, inasmuch as it serves to reinforce rather than threaten existing patronage systems. This analysis is consistent with the hypothesized relationship in Lavers and Hickey's (2016) adapted political settlements approach, that proposals are rejected, revised, or adopted based on their compatibility with the political settlement.

The extent to which the political settlement shapes social protection outcomes has been mediated by preferences and incentives emanating from the donor community. It is the convergence of the requirements of the political settlement with donor interests, policy framing, and ideation that seems to have driven the successful provision of social assistance, whereas a lack of convergence has hindered the development of SHI. Initially a donor-led agenda, cash transfer provision has becoming popular politically as part of the national agenda, ultimately presented as a nationwide presidential initiative, the Inua Jamii, in 2014 as MPs realized its potential as an additional constituency-level patronage resource, which they have successfully co-opted in recent years, resulting in the paradox that improved, and largely externally financed, social protection performance is intrinsically linked to the entrenchment of the existing political settlement. It would now be politically difficult for the government to reduce or withdraw provision, given the patronage networks that have grown around it and the fact that social protection has become an instrument of the political settlement. External funding remains a key factor in this extended provision, and plans are not yet in place for domestic resources to absorb the full cost of social protection once current donor support comes to an end, which may raise a question over longterm sustainability. However, the nature of the political settlement at this point may serve to render future financing for social protection politically irreversible, as social assistance has become incorporated as a component of the patronage structures on which the state is dependent. 


\section{References}

Abuya, T., T. Maina, and J. Chuma (2015). 'Historical Account of the National Health Insurance Formulation in Kenya: Experiences from the Past Decade'. BMC Health Services Research 15: 56. DOI: 10.1186/s12913-015-0692-8.

Aglioby, J. (2016). 'Kenya Plans Spending Cuts to Curb Surging Budget deficit'. Financial Times, 19 January. Available at: www.ft.com/cms/s/0/ab705fe6-bb82-11e5-b1518e15c9a029fb.html\#axzz4F95gVSBP (accessed 16 April 2016).

Anyang'-Nyong'o, P. (2007). A Leap into the Future: A Vision for Kenya's Socio-political and Economic Transformation. Nairobi: African Research and Resource Forum.

Barkan, J.D. (1984). 'Legislators, Elections and Political Linkage'. In J.D. Barkan (ed.), Politics and Public Policy in Kenya and Tanzania. Nairobi: Heinemann.

Barkan, J.D. (1992). 'The Rise and Fall of a Governance Realm in Kenya'. In G. Hyden and M. Bratton (ed.), Governance and Politics in Africa, Boulder, CO: Lynne Rienner Publishers.

Barkan, J.D. (1994). 'Divergence and Convergence in Kenya and Tanzania: Pressures for Reform'. In J.D. Barkan (ed.), Beyond Capitalism vs. Socialism in Kenya and Tanzania. Nairobi: East African Educational Publishers.

Booth, D., B. Cooksey, F. Golooba-Mutebi, and K. Kanyinga (2014). East African Prospects: An update on the Political Economy of Kenya, Rwanda, Tanzania and Uganda. London: ODI.

Bosworth, J., C. Alviar, L. Corral, et al. (2016). From Evidence to Action: The Story of Cash Transfers and Impact Evaluation in Sub-Saharan Africa. Oxford: Oxford University Press.

Bryant, J.H. (2009). 'Kenya's Cash Transfer Program: Protecting the Health and Human Rights of Orphans and Vulnerable Children'. Health and Human Rights, 11(2): 65-76.

Carrin, G., R. Korte, B. Schramm, and J. van Lente (2003). 'Comments and Suggestions of the Joint WHO/GTZ Mission on Social Health Insurance in Kenya'. Available at: www.who.int/health_financing/documents/1st_who_gtz_mission.pdf (accessed 20 April 2016).

Carrin, G., James, C. Adelhardt, M., et al. (2007). 'Health Financing Reform in Kenya: Assessing the Social Health Insurance Proposal'. South African Medical Journal, 97(2): 130-35.

CBK (2013). Annual Report 2013. Nairobi: Central Bank of Kenya. Available at: www.centralbank.go.ke/images/docs/CBKAnnualReports/2013annualreport.pdf (accessed 18 March 2014).

CGD (2004). 'A Leap of Faith'. Centre for Governance and Development Bills Digest, Issue 03/08. Available at: www.cgd.or.ke/documents/Ngilu\%20BillA\%20Leap\%20of\%20faith.pdf (accessed 16 March 2016).

Di John, J., and Putzel, J. (2009). 'Political Settlements Issues Paper'. Birmingham: Governance and Social Development Resource Centre, University of Birmingham. Available at: https://core.ac.uk/download/pdf/103642.pdf (accessed 16 January 2017).

Hakijamii Trust (2007). 'The Right to Social Security in Kenya: The Gap Between International Human Rights and Domestic Law and Policy'. Parallel Report to Committee on Economic, Social and Cultural Rights, Article 9 of the Covenant. Nairobi: Hakijamii Trust.

Handa, S., and S. Stewart (2008). 'No Worse Than Their Peers? Orphans' Nutritional Status in Eastern \& Southern Africa'. Unpublished manuscript. 
Hurrell, A., and Sabates-Wheeler, R. (2013). Kenya Hunger Safety Net Programme Monitoring and Evaluation Component: Quantitative Impact Evaluation Final Report-2009 to 2012'. Oxford: Oxford Policy Management.

Ikiara, K.G. (2009). 'Political Economy of Cash Transfers in Kenya'. London: ODI.

IMF (2017). 'IMF Executive Board Completes First Review Under the Stand-By Arrangement and Standby Credit Facility Arrangement for Kenya'. Press Release 17.23, 25 January. Available at: www.imf.org/en/News/Articles/2017/01/25/PR1723-Kenya-IMF-Executive-BoardCompletes-First-Review-Under-SBA-and-SCF (accessed 10 February 2017).

Institute of Economic Affairs (IEA) (2012). 'Budget Guide 2012'. Nairobi: Institute of Economic Affairs. Available at: www.ieakenya.or.ke/publications/doc_download/179-budget-guide2012-2013 (accessed 14 February 2014).

Institute of Economic Affairs (IEA) (2013). 'Budget Guide 2013'. Nairobi: Institute of Economic Affairs. Available at: www.ieakenya.or.ke/publications/doc_download/179-budget-guide2013-2014 (accessed 14 February 2014).

Institute of Economic Affairs (IEA) (2014). 'Budget Guide 2014/15'. Nairobi: Institute of Economic Affairs. Available at: www.ieakenya.or.ke/downloads.php?page=BUDGETGUIDE-2014---2015.pdf (accessed 16 January 2017).

International Fund for Agricultural Development (IFAD) (2013). 'Enabling Poor Rural People to Overcome Poverty in Kenya'. Rome: International Fund for Agricultural Development. Available at: www.ifad.org/operations/projects/regions/pf/factsheets/kenya.pdf (accessed 18 March 2014).

IPAR (2005). 'Social Health Insurance Scheme for All Kenyans: Opportunities and Sustainability Potential'. Institute for Policy Analysis and Research Policy Brief, 11(2): 1-4.

Kanyinga, K. (1995). 'The Changing Development Space in Kenya'. In Peter Gibbon (ed.), Markets, Civil Society and Democracy in Kenya. Uppsala: Nodiska Afrikainstitutet.

Kenya National Bureau of Statistics (KNBS) (2013). Exploring Kenya's Inequality: Pulling Apart or Pooling Together?. Nairobi: Kenya National Bureau of Statistics and Society for International Development.

Kenya National Bureau of Statistics (KNBS) (2014). Economic Survey 2014. Nairobi: Government Printer.

Kenya National Bureau of Statistics (KNBS) (2015). Economic Survey 2014. Nairobi: Government Printer.

Kenya National Bureau of Statistics (KNBS) (2016). Economic Survey 2014. Nairobi: Government Printer.

Khan, M. (2010), 'Political Settlements and the Governance of Growth-Enhancing Institutions'. Unpublished manuscript. Available at: http://eprints.soas.ac.uk/9968 (accessed 16 January 2017).

Kirera, P.G. (2012). Implications of Cash Transfer Programmes for Social Relations: Kenya's Cash Transfer for Orphans and Vulnerable Children (OVC-CT). The Hague: Institute of Social Studies.

Kiringai, J. (2006). 'Public Spending in Kenya: An Inequality Perspective'. In Society for International Development, Readings on Inequality in Kenya: Sectoral Dynamics and Perspectives. Nairobi: Society for International Development.

Lakin, J., and V. Magero (2012). 'Healthy Ambitions? Kenya's National Hospital Insurance Fund Must Become More Transparent if it is to Anchor Universal Health Coverage'. Budget Brief 
14. Nairobi: International Budget Partnership. Available at: www.internationalbudget.org/publications/brief14 (accessed 10 February 2017).

Lavers, T., and S. Hickey (2016). 'Conceptualising the Politics of Social Protection Expansion in Low Income Countries: The Intersection of Transnational Ideas and Domestic Politics'. International Journal of Social Welfare 25: 388-98. DOI: 10.1111/ijsw.12210.

Masime, K., and G. Kibara (2003). 'Regime Transitions and the Institutionalization of Democracy in Kenya: The December 2002 Elections and Beyond', The East African Journal of Democracy and Human Rights, 1(1): 13-29.

Mathiu, P., and E.K. Mathiu (2012). 'Social Protection for the Elderly as a Development Strategy: A Case Study of Kenya's Old Persons Cash Transfers Programme'. Paper presented the III International Conference of IESE on 'Mozambique: Accumulation and Transformation in a Context of International Crisis', Maputo, 4-5 September.

McCord, A. (2006). 'Overview of Social Protection Systems in Kenya'. Working Paper. Nairobi: GoK/UNICEF.

McCord, A., Yablonski, J., and Winder Rossi, N. (2016). 'The Political Economy of Cash Transfer Evaluations in Sub-Saharan Africa'. In B. Davis, S. Handa, N. Hypher et al. (eds), From Evidence to Action, The Story of Cash Transfers and Impact Evaluation in Sub-Saharan Africa. Oxford: FAO, UNICEF and Oxford University Press.

Ministry of Health (2004). 'Sessional Paper on National Social Health Insurance in Kenya'. Nairobi: Ministry of Health.

Muiya, B.M., and Kamau, A. (2013). 'Universal Health Care in Kenya: Opportunities and Challenges for the Informal Sector Workers'. International Journal of Education and Research, 1(11): $1-10$.

Mung'ahu, A. (2013). 'Ex-NHIF Boss Kerich is Charged with Fraud'. The Star, 6 November. Available at: www.the-star.co.ke/news/2013/11/06/ex-nhif-boss-kerich-is-charged-withfraud_c854010 (accessed 10 February 2017).

Murunga, G.R., and S.W. Nasong'o (2006). 'Bent on Self-destruction: The Kibaki Regime in Kenya'. Journal of Contemporary African Studies, 24(1): 1-28.

Mwangi, L. (n.d.) 'Inua Jamii Cash Programme Launched by President Uhuru'. Zakenya. Available at: www.zakenya.com/services/inua-jamii-cash-programme-launched-by-presidentuhuru.html (accessed 10 February 2017).

Mwasiaji, W. (2015). 'Scaling up Cash Transfer Programmes in Kenya', One Pager, 289: 1. Available at:

undp.org/pub/eng/OP286_Scaling_up_Cash_Transfer_Programmes_in_Kenya.pdf (accessed 14 March 2016).

Mwasiaji, W., K. Reidel, E.S. Mistiaen, J. Sandford, and M.M. Munavu (2016). Inua Jamii: Towards a More Effective National Safety Net for Kenya. Washington, DC: World Bank Group. Available at: $\quad$ http://documents.worldbank.org/curated/en/949781468198008332/Inua-Jamiitowards-a-more-effective-national-safety-net-for-Kenya (accessed 10 February 2017).

Mwaura, R.N., E.W. Barasa, G.N.V. Ramana, J.A. Coarasa, and K.O. Rogo (2015). 'The Path to Universal Health Coverage in Kenya: Repositioning the Role of the National Hospital Insurance Fund'. IFC Smart Lessons Brief. Washington, DC: World Bank Group. Available at: http://documents.worldbank.org/curated/en/2015/08/24943477/path-universalhealth-coverage-kenya-repositioning-role-national-hospital-insurance-fund (accessed on 21 April 2016). 
National Gender and Equality Commission (2014). 'Participation of Vulnerable Populations in Their Own Programmes: The Cash Transfers in Kenya'. Nairobi: National Gender and Equality Commission.

NDMA (2014). 'Hunger Safety Net Programme 2'. Available at: www.hsnp.or.ke/filedownload.php?download_file=HSNP2_Presentation.pdf (accessed 15 December 2015).

NHIF (2016). 'About Us’. Available at: www.nhif.or.ke/healthinsurance (accessed 20 April 2016).

Nyambedha, E.O., S. Wandibba, and J. Aagaard-Hansen (2003). “Retirement lost”: The New Role of the Elderly as Caretakers for Orphans in Western Kenya'. Journal of Cross-Cultural Gerontology, 18(1): 32-52.

Okello, D., and M.J. Gitau (2006). 'Introduction and Overview'. In Society for International Development, Readings on Inequality in Kenya: Sectoral Dynamics and Perspectives. Nairobi: Society for International Development.

Okumu, J.J., and F. Holmquist (1984). 'Party and Party-State Relations'. In J.D. Barkan (ed.), Politics and Public Policy in Kenya and Tanzania. Nairobi: Heinemann.

Oyugi, W.O. (1992). 'Uneasy Alliance: Party-State Relations in Kenya'. In W.O. Oyugi (ed.), Politics and Administration in East Africa. Nairobi and Bonn: Konrad Adenauer Foundation.

Pearson, R., and C. Alviar (2006). 'The Evolution of the Government of Kenya Cash Transfer Programme for Vulnerable Children between 2002 and 2006 and Prospects for Nationwide Scale-up'. Nairobi: UNICEF Kenya. Available at: www.unicef.org/infobycountry/files/The_Evolution_of_the_Government_of_Kenya_Cas h_Transfer_Programme_for_Vulnerable_Children.pdf (accessed 10 April 2016).

Republic of Kenya (RoK) (2003). Economic Recovery Strategy for Wealth and Employment Creation, 20032007. Nairobi: Ministry of Planning and National Development.

Republic of Kenya (RoK) (2007). Kenya Vision 2030. Nairobi: Government of the Republic of Kenya. Available at: www.vision2030.go.ke/lib.php?f=vision-2030-popular-version (accessed 16 February 2017).

Republic of Kenya (RoK) (2009). 'Draft Social Protection Strategy, 2009-2012'. Nairobi: Ministry of Gender, Children and Social Services.

Republic of Kenya (RoK) (2010). The Constitution of Kenya 2010. Nairobi: Government Printer.

Republic of Kenya (RoK) (2011). Kenya National Social Protection Policy. Nairobi: Ministry of Gender, Children and Social Development.

Republic of Kenya (RoK) (2012). Kenya Social Protection Sector Review: Executive Report. Nairobi: Ministry of State for Planning, National Development and Vision 2030. Available at: www.planning.go.ke (accessed 10 February 2017).

Republic of Kenya (RoK) (2016). Inua Jamii: Towards a More Effective National Safety Net for Kenya: Progress Report. Nairobi: Ministry of Labour and East African Affairs. Available at: http://documents.worldbank.org/curated/en/949781468198008332/pdf/105760-WP-

P131305-PUBLIC.pdf (accessed 13 February 2017).

Society for International Development (SID) and Kenya National Bureau of Statistics (KNBS) (2013). Exploring Kenya's Inequality: Pulling Apart or Pooling Together? Nairobi: SID and KNBS.

Sundet, G., and E. Moen (2009). 'Political Economy Analysis of Kenya'. NORAD Report 19/2009 Discussion. Oslo: Norwegian Agency for Development Cooperation.

UN Statistics Division (2016). World Statistics Pocketbook, 2016 Edition. New York: United Nations. 
UNAIDS (2013). Global Report: UNAIDS Report on the Global AIDS Epidemic 2013. Geneva: UNAIDS.

UNDP (2013). Human Development Reports: Income Gini Coefficient'. New York: UNDP. Available at: http://hdr.undp.org/en/content/income-gini-coefficient (accessed 17 October 2014).

UNICEF and UNAIDS (2003). Africa's Orphaned Generations. Geneva: UNICEF and UNAIDS. Available at: www.unicef.org/sowc06/pdfs/africas_orphans.pdf (accessed 10 February 2017).

Wanyama, F.O., and E.O. Nyambedha (2015). 'The Political Economy of Social Protection Policy Uptake in Kenya'. Research Report. Nairobi: Partnership for Social and Governance Research.

World Bank (2013a). Technical Assessment of the Kenya National Safety Net Program for Results. Washington, DC: World Bank.

World Bank (2013b). National Safety Net Programme for Results. Nairobi: World Bank.

World Bank (2013c). 'Kenya Health Sector Support Project: Additional Financing'. Available at: www.worldbank.org/projects/P144197/?lang=en\&tab=details (accessed 10 February 2017). 